Article

\title{
Production of a New Cyclic Depsipeptide by the Culture Broth of Staphylococcus sp. Isolated from Corallina officinalis L.
}

\author{
Reda F. A. Abdelhameed ${ }^{1}\left(\mathbb{D}\right.$, Sameh S. Elhady ${ }^{2,3}{ }^{\circledR}$, Ahmad O. Noor ${ }^{4}$, Diena M. Almasri ${ }^{4}$, \\ Alaa A. Bagalagel ${ }^{4}$, Galal T. Maatooq ${ }^{5,6}$, Amgad I. M. Khedr ${ }^{3}$ and Koji Yamada ${ }^{7, *}$ \\ 1 Department of Pharmacognosy, Faculty of Pharmacy, Suez Canal University, Ismailia 41522, Egypt; \\ omarreda_70@yahoo.com \\ 2 Department of Natural Products and Alternative Medicine, Faculty of Pharmacy, King Abdulaziz University, \\ Jeddah 21589, Saudi Arabia; ssahmed@kau.edu.sa \\ 3 Department of Pharmacognosy, Faculty of Pharmacy, Port Said University, Port Said 42526, Egypt; \\ a_mansour7799@yahoo.com \\ 4 Department of Pharmacy Practice, Faculty of Pharmacy, King Abdulaziz University, \\ Jeddah 21589, Saudi Arabia; aonoor@kau.edu.sa (A.O.N.); dalmasri@kau.edu.sa (D.M.A.); \\ abagalagel@kau.edu.sa (A.A.B.) \\ 5 Department of Pharmacognosy, Faculty of Pharmacy, The Islamic University in Najaf, Najaf 54001, Iraq; \\ galaltm@yahoo.com \\ 6 Department of Pharmacognosy, Faculty of Pharmacy, Mansoura University, Mansoura 35516, Egypt \\ 7 Garden for Medicinal Plants, Graduate School of Biomedical Sciences, Nagasaki University; \\ Bunkyo-machi 1-14, Nagasaki 852-8521, Japan \\ * Correspondence: kyamada@nagasaki-u.ac.jp; Tel.: +81-95-819-2462
}

Received: 13 October 2019; Accepted: 9 November 2019; Published: 11 November 2019

\begin{abstract}
A new cyclic depsipeptide (1) has been isolated from culture broth of Staphylococcus sp. (No. P-100826-4-6) derived from Corallina officinalis L., together with the known compounds indol-3-carboxylic acid (2), 1,5-dideoxy-3-C-methyl arabinitol (3), thymine (4), uracil (5), cyclo (L-pro-L-omet) (6) and macrolactin B (7). The structure of (1) was established to be cyclo $(2 \alpha, 3$-diaminopropoinc acid-L-Asn-3- $\beta$-hydroxy-5-methyl-tetradecanoic acid-L-Leu ${ }^{1}$-L-Asp-L-Val-L-Leu ${ }^{2}$-L-Leu ${ }^{3}$ ) by extensive spectroscopic techniques including ${ }^{1} \mathrm{H}$ NMR, ${ }^{13} \mathrm{C}$ NMR, ${ }^{1} \mathrm{H}-{ }^{1} \mathrm{H}$ COSY, HMBC, HSQC, NOESY, and HRFABMS. The antimicrobial activities of compounds 1-7 were evaluated. Compounds 1-5, and 7 showed moderate antimicrobial activity while compound 6 exhibited a potent antimicrobial and antifungal activities.
\end{abstract}

Keywords: Corallina officinalis; Staphylococcus sp.; cyclic depsipeptide; antimicrobial assay

\section{Introduction}

Bioprospecting studies of endophytic microorganisms play a principal part in the discovery of lead compounds for the improvement of drugs for the management of humanity's diseases [1-3]. Marine microorganisms are widely recognized as promising sources of secondary metabolites [2,4-6]. These organisms, prosperous in diverse marine environments, have produced a wide variety of structurally exclusive and biologically active compounds that have attracted significant interest for biomedical researches [4,7-9].

In the last decade, a significantly increased interest in the isolation of bioactive secondary metabolites from marine microbes has been reported [10]. Peptides, which were derived from different organisms including marine microbes, represent an important chemical class with diverse structures 
and significant biological activities. The biological activity of marine-derived peptides has been shown to depend on the composition and sequence of amino acids, their structural properties, as well as on the environmental habitat for producer bacteria [11,12]. These substances are actively synthesized by marine microorganisms during their life cycle [13]. To date, lots of peptide metabolites, which are consisting of 20-40 amino acids, have been separated from various marine microorganisms $[11,12,14]$. Most of them are capable of quick inhibition or killing of a wide range of microbes. Other antimicrobial peptides (proteins consisting of 100 or more amino acids) disrupt the function or the structure of microbial cell membranes by binding to specific targets $[15,16]$.

In our pursuit of isolation of natural compounds from marine sources [17-20], chemical investigation for the antimicrobial extract of Staphylococcus sp. No. [P-100826-4-6] derived, was carried out. This study led to discovery of a new natural cyclic depsipeptide (1) along with six known compounds; indol-3-carboxylic acid (2) [21], 1,5-dideoxy-3-C-methyl arabinitol (3) [22], thymine (4) [21], uracil (5) [23], cyclo (L-pro-L-omet) (6) [24], and macrolactin B (7) [25] (Figure 1). Therefore, structure identification of the isolated pure compounds $1-7$ and their antimicrobial activity will be discussed.

\section{Results and Discussion}

\subsection{Isolation Method of Compounds 1-7}

The fermented broth of the marine bacterium Staphylococcus sp. No. [P-100826-4-6] was extracted with different organic solvents. Successive fractionation of the combined extracts was done using silica gel column chromatography based on increasing polarity, Sephadex LH-20, Diaion HP-20, reversed-phase C18 silica gel column; subsequently, final purification on a C18 RP-HPLC column gave seven compounds 1-7 (Figure 1).

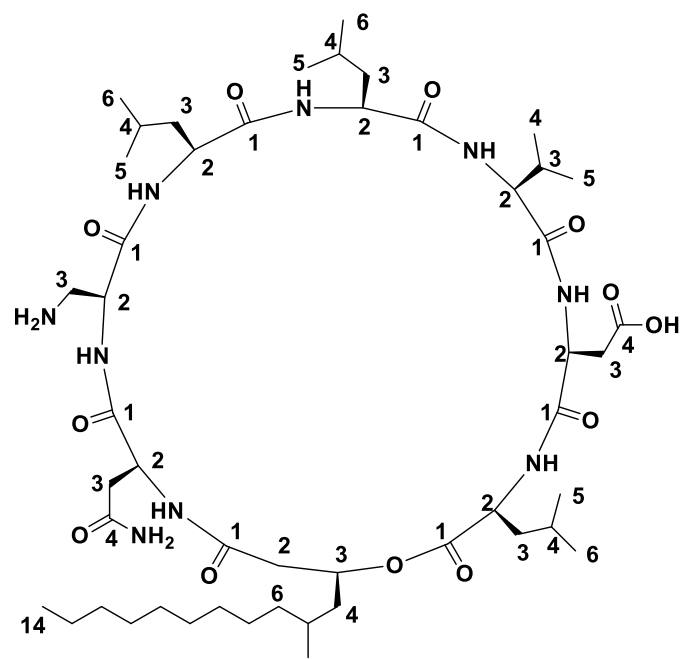<smiles>O=C(O)c1c[nH]c2ccccc12</smiles>

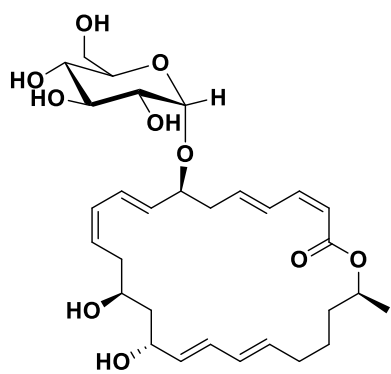

6

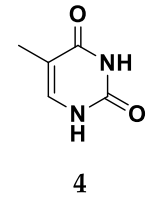<smiles></smiles>
5<smiles>CS(=O)CCC1NC(=O)C2CCCN2C1=O</smiles>

7

Figure 1. Structure of compounds 1-7.

\subsection{Characterization of Compounds 1-7 Structures}

Compound 1 (Figure 1) was obtained as a white amorphous powder by several chromatographic procedures obtained from the fermented broth of Staphylococcus species. It gave a $[\mathrm{M}+\mathrm{H}]^{+}$peak in the (FABMS) at $\mathrm{m} / z 994.7$ and (HRFABMS) elemental composition $[\mathrm{M}+\mathrm{Na}]^{+}$at $\mathrm{m} / \mathrm{z} 1016.6396$ (calcd for $\mathrm{C}_{49} \mathrm{H}_{87} \mathrm{~N}_{9} \mathrm{NaO}_{12}, 1016.6372, \Delta+2.5 \mathrm{mmu}$ ) (Figures S1-S3) indicating 11 degrees of unsaturation. The ${ }^{1} \mathrm{H}$ NMR spectrum of $\mathbf{1}$ (Table 1, Figure S4) with HSQC and HMBC spectral data confirmed the existence of 8 methine protons $(\mathrm{C}-\mathrm{H})\left[\delta_{\mathrm{H}} 5.64,5.64,5.05,4.98,4.90,4.83,4.70,4.62,1 \mathrm{H}\right.$ each], 7 amide protons $\mathrm{NH}-\mathrm{C}=\mathrm{O}\left[\delta_{\mathrm{H}} 9.58,9.48,9.20,8.91,8.83,8.75,8.41\right.$, partially overlapped, $1 \mathrm{H}$ each $]$, 10 methyl groups, among them 9 methyl doublets $\left[\delta_{\mathrm{H}} 1.17,1.13,1.02,0.96,0.95,0.93,0.92,0.85,3 \mathrm{H}\right.$ 
each, $\mathrm{d}, J=6.6 \mathrm{~Hz}]$, one methyl triplet $\left[\delta_{\mathrm{H}} 0.81,3 \mathrm{H}, \mathrm{t}, J=6.9 \mathrm{~Hz}\right]$ and long methylene chain centered at $\delta_{\mathrm{H}} 1.22(12 \mathrm{H}, \mathrm{brs})$. The ${ }^{13} \mathrm{C}$ NMR and DEPT spectra of $\mathbf{1}$ (Table 1, Figure S5) with HSQC and HMBC spectral data exhibited 49 signals, attributable to 10 carbonyl carbons $\left[\delta_{\mathrm{C}} 175.6,175.5,174.8\right.$, $173,8,173.6,173.4,172.5,172.4,172.0$, and 171.7], 7 bearing nitrogen methines $\left[\delta_{C} 61.0,55.0,53.5\right.$, $52.7,52.5,52.5$, and 51.5], one oxymethine [ $\left.\delta_{C} 72.5\right], 5$ methines [ $\delta_{C} 28.5,25.4,25.3,25.1$, and 24.9] 10 methyls $\left[\delta_{C} 23.6,23.4,23.2,22.8,21.8,21.5,21.5,19.5,18.7\right.$, and 14.4], 16 methylenes (Table 1). We could easily deduce that 1 was depsipeptide composed of 1 Val, 3 Leu, 1 Asn, 1 Asp, and 1 A 2 pr residues interlinked with 3-hydroxy-5-methyl fatty acid by analysis of HSQC, HMBC, COSY and NOESY (Figures S6-S9) correlations as shown in Figure 2. The sequence of amino acids in $\mathbf{1}$ was identified by NOESY and HMBC data analysis for $\mathbf{1}$ as in Figure 2. NOESY correlations found in $\mathbf{1}$ between $\mathrm{NH}$ protons and adjacent amino acids methine protons clearly identified the following amide bonds: Asp-CO/Val-NH ( $\delta_{\mathrm{H}}$ 4.83/9.48), HMTDA-CO/Asn-NH $\left(\delta_{\mathrm{H}}\right.$ 5.64/8.91), HMTDA-CO/Leu ${ }^{1}-\mathrm{NH}$ $\left(\delta_{\mathrm{H}} 5.64 / 8.41\right)$. The connectivity between HMFA and Leu ${ }^{1}$ was also identified by NOESY correlation between $\alpha$-methine proton HMFA and $\mathrm{NH}$ proton of $\operatorname{Leu}^{1}\left(\delta_{\mathrm{H}} 5.64 / 8.41\right)$ and Asn $\left(\delta_{\mathrm{H}} 5.64 / 8.91\right)$. These data, together with HMBC correlations as shown in Figure 2, finally enable us to set up the structure of $\mathbf{1}$ as cyclo (-A ${ }_{2}$ Pr-Asn-HMTDA-Leu ${ }^{1}$-Asp-Val-Leu ${ }^{2}-$ Leu $^{3}$-). FABMS data of $\mathbf{1}$ (Figures S2 and S3) supported the amino acid sequence of $\mathbf{1}$ as shown in Table 2 . The amino acids absolute configuration of $\mathbf{1}$ was recognized by the reaction of Marfey's reagent $[26,27]$ with the crude hydrolysate followed by co-injection of standard amino acids using HPLC analysis. The hydrolysate was recognized to possess $3 \mathrm{~L}-\mathrm{Leu}, 1 \mathrm{~L}-\mathrm{Val}$, and $1 \mathrm{~L}-\mathrm{Asp}$. The configuration of $\mathrm{A}_{2} \mathrm{Pr}$ and C-3 of HMTDA were proposed by cautions analysis of NOESY correlations, as shown in Figure 2. The NOESY correlation between $\beta$-proton $\left(\delta_{\mathrm{H}} 5.64\right)$ of HMTDA and amide proton $\left(\delta_{\mathrm{H}} 8.91\right)$ of Asn, between amide proton $\left(\delta_{\mathrm{H}} 8.91\right)$ of Asn and $\alpha$-proton $\left(\delta_{\mathrm{H}} 4.90\right)$ of Asn, between amide proton $\left(\delta_{\mathrm{H}} 9.20\right)$ of $\mathrm{A}_{2} \operatorname{Pr}$ and $\alpha$-proton $\left(\delta_{\mathrm{H}} 5.64\right)$ of $\mathrm{A}_{2} \mathrm{Pr}$, between amide proton $\left(\delta_{\mathrm{H}} 9.58\right)$ of $\mathrm{Leu}^{3}$ and $\alpha$-proton $\left(\delta_{\mathrm{H}} 4.62\right)$ of $\mathrm{Leu}^{3}$, between amide proton $\left(\delta_{\mathrm{H}} 8.75\right)$ of $\mathrm{Leu}^{2}$ and $\alpha$-proton $\left(\delta_{\mathrm{H}} 4.98\right)$ of $\mathrm{Leu}^{2}$, between amide proton $\left(\delta_{\mathrm{H}} 9.48\right)$ of Val and $\alpha$-proton $\left(\delta_{\mathrm{H}} 4.70\right)$ of Val, revealed that the configuration at $\mathrm{A}_{2} \mathrm{Pr}$ and C-3 of HMTDA have the configuration of L-Leu, L-Val, and L-Asp. Therefore, the final structure of $\mathbf{1}$ was lastly characterized as cyclo ( $2 \alpha$, 3-diamino-propoincacid-L-Asn-3- $\beta$-hydroxy-5-methyl-tetradecanoicacid-L-Leu ${ }^{1}$-L-AspL-Val-L-Leu ${ }^{2}$-L-Leu ${ }^{3}$ ).

Table 1. ${ }^{1} \mathrm{H}$ and ${ }^{13} \mathrm{C}$ NMR data of compound $\mathbf{1}\left(\text { pyridine- } d_{5}\right)^{\mathrm{a}}$.

\begin{tabular}{|c|c|c|c|c|c|}
\hline Position & $\delta_{\mathrm{H}}(\mathrm{m}, J$ in $\mathrm{Hz})$ & $\delta_{\mathrm{C}}$ & Position & $\delta_{\mathrm{H}}(\mathrm{m}, J$ in $\mathrm{Hz})$ & $\delta_{\mathrm{C}}$ \\
\hline L-Leu ${ }^{1}$ & & & 2 & $4.62 \mathrm{~m}$ & $52.5(\mathrm{CH})$ \\
\hline 1 & - & $173.4(\mathrm{C})$ & 3 & $2.10 \mathrm{~m}$ & $40.0\left(\mathrm{CH}_{2}\right)$ \\
\hline 2 & $5.05 \mathrm{~m}$ & $52.7(\mathrm{CH})$ & 4 & $1.97 \mathrm{~m}$ & $25.1(\mathrm{CH})$ \\
\hline 3 & $1.97,2.10 \mathrm{~m}$ & $39.5\left(\mathrm{CH}_{2}\right)$ & 5 & $1.02 \mathrm{~d}(6.6)$ & $23.4\left(\mathrm{CH}_{3}\right)$ \\
\hline 4 & $1.97 \mathrm{~m}$ & $24.9(\mathrm{CH})$ & 6 & $0.95 \mathrm{~d}(6.6)$ & $21.5\left(\mathrm{CH}_{3}\right)$ \\
\hline 5 & $0.91 \mathrm{~d}(6.6)$ & $21.3\left(\mathrm{CH}_{3}\right)$ & $\mathrm{NH}$ & 9.58 br s & - \\
\hline 6 & $0.85 \mathrm{~d}(6.6)$ & $22.8\left(\mathrm{CH}_{3}\right)$ & $\mathrm{A}_{2} \mathrm{Pr}$ & & \\
\hline $\mathrm{NH}$ & $8.41 \mathrm{br} \mathrm{s}$ & & 1 & - & $173.8(\mathrm{C})$ \\
\hline L-Asp & & & 2 & $5.64 \mathrm{~m}$ & $51.5(\mathrm{CH})$ \\
\hline 1 & - & $172(\mathrm{C})$ & 3 & $\begin{array}{l}3.62 \mathrm{dd}(15.8,8.8) \\
3.40 \mathrm{dd}(15.8,4.8)\end{array}$ & $37.3\left(\mathrm{CH}_{2}\right)$ \\
\hline 2 & $4.83 \mathrm{~m}$ & $53.5(\mathrm{CH})$ & $\mathrm{NH}$ & $9.20 \mathrm{br} \mathrm{s}$ & - \\
\hline 3 & $1.97,2.67 \mathrm{~m}$ & $33.7\left(\mathrm{CH}_{2}\right)$ & $\mathrm{NH}_{2}$ & Not observed & - \\
\hline 4 & & $175.6(\mathrm{C})$ & L-Asn & & \\
\hline $\mathrm{NH}$ & 8.83 (1H, brs) & - & 1 & - & $173.6(\mathrm{C})$ \\
\hline L-Val & & & 2 & $4.90 \mathrm{~m}$ & $55.0(\mathrm{CH})$ \\
\hline 1 & - & $172.5(\mathrm{C})$ & 3 & $2.67,2.90 \mathrm{~m}$ & $35.0\left(\mathrm{CH}_{2}\right)$ \\
\hline 2 & $4.70 \mathrm{t}(6.6)$ & $61.0(\mathrm{CH})$ & 4 & - & $175.5(\mathrm{C})$ \\
\hline 3 & $2.67 \mathrm{~m}$ & $28.5(\mathrm{CH})$ & $\mathrm{NH}$ & 8.91 br s & - \\
\hline 4 & $1.17 \mathrm{~d}(6.6)$ & $19.5\left(\mathrm{CH}_{3}\right)$ & $\mathrm{NH}_{2}$ & Not observed & - \\
\hline
\end{tabular}


Table 1. Cont.

\begin{tabular}{cccccc}
\hline Position & $\delta_{\mathbf{H}}(\mathbf{m}, \boldsymbol{J}$ in $\mathbf{H z})$ & $\delta_{\mathbf{C}}$ & Position & $\delta_{\mathbf{H}}(\mathbf{m}, \boldsymbol{J}$ in Hz) & $\delta_{\mathbf{C}}$ \\
\hline 5 & $1.13 \mathrm{~d}(6.6)$ & $18.7\left(\mathrm{CH}_{3}\right)$ & HMTDA & & \\
NH & $9.48 \mathrm{br} \mathrm{s}$ & - & 1 & - & $171.7(\mathrm{C})$ \\
L-Leu $^{2}$ & & & 2 & $2.94,2.90 \mathrm{~m}$ & $43.0\left(\mathrm{CH}_{2}\right)$ \\
1 & - & $172.4(\mathrm{C})$ & 3 & $5.64 \mathrm{~m}$ & $72.5(\mathrm{CH})$ \\
2 & $4.98 \mathrm{q}(7.9)$ & $52.5(\mathrm{CH})$ & 4 & $1.76 \mathrm{~m}$ & $42.6\left(\mathrm{CH}_{2}\right)$ \\
3 & $2.10 \mathrm{~m}$ & $39.6\left(\mathrm{CH}_{2}\right)$ & 5 & $1.40 \mathrm{~m}$ & $25.4\left(\mathrm{CH}^{2}\right)$ \\
4 & $1.97 \mathrm{~m}$ & $25.3\left(\mathrm{CH}^{2}\right)$ & $5 \mathrm{Me}$ & $0.93 \mathrm{~d}(6.6)$ & $23.6\left(\mathrm{CH}_{3}\right)$ \\
5 & $0.96 \mathrm{~d}(6.6)$ & $23.2\left(\mathrm{CH}_{3}\right)$ & 6 & 1.29 (overlapped) & $32.0\left(\mathrm{CH}_{2}\right)$ \\
6 & $0.92 \mathrm{~d}(6.6)$ & $21.8\left(\mathrm{CH}_{3}\right)$ & $7-12$ & $1.22 \mathrm{~m}$ & $28.7-29.0$ \\
NH & $8.75 \mathrm{br} \mathrm{s}$ & - & 13 & 1.33 (overlapped) & $22.9\left(\mathrm{CH}_{2}\right)$ \\
L-Leu & & & 14 & $0.81 \mathrm{t}(6.9)$ & $14.4\left(\mathrm{CH}_{3}\right)$ \\
1 & - & $174.8(\mathrm{C})$ & & & \\
\hline
\end{tabular}

a Spectra were acquired at $23^{\circ} \mathrm{C}$. Chemical shifts were given in $\delta(\mathrm{ppm})$.

Table 2. (+) FABMS parent and fragment ions of compound 1.

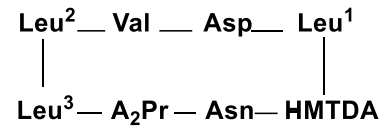

\begin{tabular}{|c|c|}
\hline Fragments & $m / z$ \\
\hline$\left[\mathrm{Leu}^{3}-\mathrm{A}_{2} \mathrm{Pr}-\mathrm{Asn}-\mathrm{HMTDA}-\mathrm{Leu}^{1}-\mathrm{Asp}-\mathrm{Val}-\mathrm{Leu}^{2}\right]^{+}$ & 994.7 \\
\hline$\left[\mathrm{Leu}^{3}-\mathrm{A}_{2} \mathrm{Pr}-\mathrm{Asn}-\mathrm{HMTDA}-\mathrm{Leu}^{1}-\mathrm{Asp}-\mathrm{Val}\right]^{+}$ & 881.6 \\
\hline$\left[\mathrm{A}_{2} \mathrm{Pr}-\mathrm{Asn}-\mathrm{HMTDA}-\mathrm{Leu}^{1}-\mathrm{Asp}^{+}\right.$ & 669.6 \\
\hline$\left[\mathrm{A}_{2} \operatorname{Pr}-\mathrm{Asn}-\mathrm{HMTDA}-\mathrm{Leu}^{1}\right]^{+}$ & 554.6 \\
\hline$\left[\mathrm{A}_{2} \mathrm{Pr}-\mathrm{Asn}-\mathrm{HMTDA}\right]^{+}$ & 441.4 \\
\hline$\left[\mathrm{A}_{2} \mathrm{Pr}-\mathrm{Asn}\right]^{+}$ & 201.2 \\
\hline
\end{tabular}

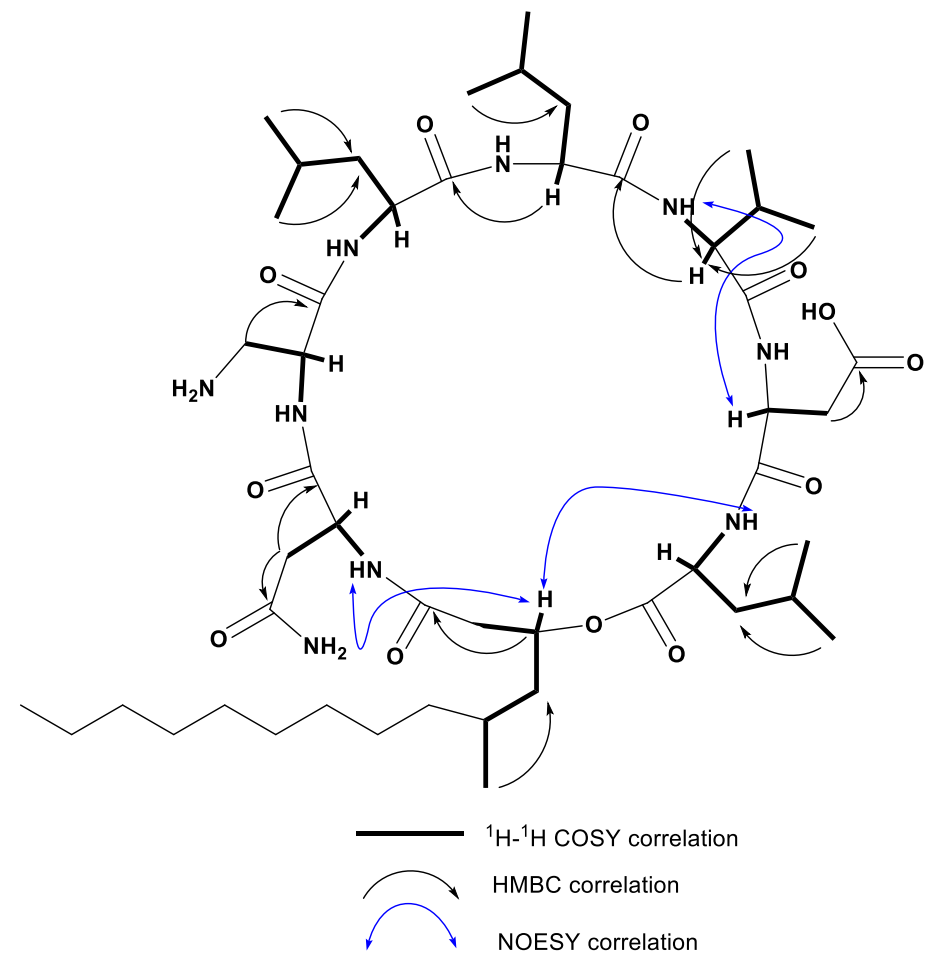

Figure 2. Selected correlations of COSY, HMBC, and NOESY observed for compound 1. 
The other known compounds 2-7, were established by analysis of their spectroscopic data (MS and NMR), and with comparison of these data with those mentioned in the literature to be: indol-3-carboxylic acid (2) [21], 1,5-dideoxy-3-C-methyl arabinitol (3) [22], thymine (4) [21], uracil (5) [23], cyclo (L-pro-L-omet) (6) [24], and macrolactin B (7) [25] as shown in Figure 1.

\subsection{Biological Activities of the Pure Compounds 1-7}

The antimicrobial activities (Table 3) of compounds 1-7 were examined for their growth inhibition of 6 microorganisms including Gram-negative, Gram-positive bacteria and fungi using paper disk method with replication $(n=2)$. The antimicrobial activities were studied in a concentration of $100 \mu \mathrm{g} /$ disk. As a result, compounds 1-5, and 7 showed moderate activity against Schizophyllum commune, Staphylococcus aureus subsp. aureus, and Escherichia coli, with inhibition zones between 9 and 13, while compound 6 exhibited a significant antifungal activity against Aspergillus niger, Penicillum crustosum, and Schizophyllum commune, with inhibition zones of 16, 18 and 23. Furthermore, compound 6 showed antibacterial activity against Staphylococcus aureus subsp. aureus, Pseudomonas aeruginosa and Escherichia coli, with inhibition zones of 20, 25 and 21 as shown in Table 3.

Table 3. Antimicrobial activities of compounds 1-7.

\begin{tabular}{|c|c|c|c|c|c|c|}
\hline \multirow{2}{*}{ Compound } & \multicolumn{6}{|c|}{ Inhibition Zone (mm, $100 \mu \mathrm{g} / \mathrm{disc})$} \\
\hline & S. aureus & E. coli & P. aeruginosa & S. commune & P. crustosum & A. niger \\
\hline 1 & 13 & 11 & NA & 11 & NA & NA \\
\hline 2 & 11 & 9 & NA & 13 & NA & NA \\
\hline 3 & 10 & 13 & NA & 12 & NA & NA \\
\hline 4 & 10 & 12 & NA & 11 & NA & NA \\
\hline 5 & 12 & 11 & NA & 10 & NA & NA \\
\hline 6 & 20 & 21 & 25 & 23 & 18 & 16 \\
\hline 7 & 13 & 10 & NA & 13 & NA & NA \\
\hline Ciprofloxacin $^{\text {a }}$ & 23 & 24 & 29 & & & \\
\hline Nystatin $\mathbf{b}$ & & & & 23 & 20 & 19 \\
\hline
\end{tabular}

The minimum inhibitory concentration (MIC) of compound 6 were evaluated. As a result, compound 6 exhibited a potent antifungal activity against Aspergillus niger, Penicillum crustosum, and Schizophyllum commune with MIC value of $50 \mu \mathrm{g} / \mathrm{mL}$. Additionally, compound $\mathbf{6}$ showed antibacterial activity against Staphylococcus aureus subsp. aureus, Pseudomonas aeruginosa and Escherichia coli, with MIC value of $100 \mu \mathrm{g} / \mathrm{mL}$.

\section{Materials and Methods}

\subsection{General Experimental Procedures}

Optical rotations were considered using JASCO DIP-370 digital polarimeter. IR spectra were obtained with JASCO FT/IR-410 spectrophotometers. ${ }^{1} \mathrm{H}$ and ${ }^{13} \mathrm{C}$ NMR, HSQC, ${ }^{1} \mathrm{H}-{ }^{1} \mathrm{H}$ COSY, HMBC, and NOESY spectra were obtained using Unity plus 500 spectrometer (Varian Inc., Palo Alto, CA, USA) operating at $125 \mathrm{MHz}$ for ${ }^{13} \mathrm{C}$ and $500 \mathrm{MHz}$ for ${ }^{1} \mathrm{H}$. Chemical shifts of ${ }^{1} \mathrm{H}-\mathrm{NMR}$ and ${ }^{13} \mathrm{C}$ NMR are expressed in $\delta$ values referring to the solvent peak $\delta_{\mathrm{H}} 7.19,7.55$ and 8.71, $\delta_{\mathrm{C}} 123.5,135.5$ and 149.9 for pyridine- $d_{5}$, and coupling constants are expressed in Hz. TLC was carried out on aluminum-backed plates (Merck, Kieselgel $60 \mathrm{~F}_{254}, 0.25 \mathrm{~mm}$ ) and RP-18 $\mathrm{F}_{254 \mathrm{~s}}$ plates (Merck). Si-gel F254 with a particle size of 0.0045-0.075 mm mesh (Wako Pure Chemical Industries Ltd., Osaka, Japan), Cosmosil 5C18-140 PREP (Nacalai tesque, No.379-34), and Sephadex LH-20 (Sigma-Aldrich, Darmstadt, Germany) were used as stationary phases for column chromatography. High resolution FABMS were obtained using JMS DX-303 spectrometer (JEOL Ltd., Tokyo, Japan). Preparative HPLC was utilized using a Develosil 
C-30-UG-5 $(250 \times 4.6 \mathrm{~mm}$ i.d Nomura Chemical Co., Aichi, Japan) adjusting the rate of flow at $1.5 \mathrm{~mL} / \mathrm{min}$, and a TOSOH RI-8020 detector.

\subsection{Biological Materials}

The isolated strain Staphylococcus sp. P-100826-4-6 (Figure 3) was obtained from Corallina officinalis, collected in Nagasaki Shitsu coast, Japan, in 2010. The voucher specimen was maintained at Garden for Medicinal Plants, Graduated School of Biomedical Sciences, Nagasaki University. Staphylococcus sp. was cultured on a medium based on sea water composed of $\left(0.1 \% \mathrm{MgSO}_{4}, 0.3 \% \mathrm{KH}_{2} \mathrm{PO}_{4}, 0.3 \%\right.$ yeast extract, $0.5 \%$ polypeptone, $1 \%$ glucose, $25 \%$ distilled water, $75 \%$ sea water) for 28 days at $25{ }^{\circ} \mathrm{C}$ on a rotary shaker. After culturing, sonication and filtration of the broth (32L) was conducted.

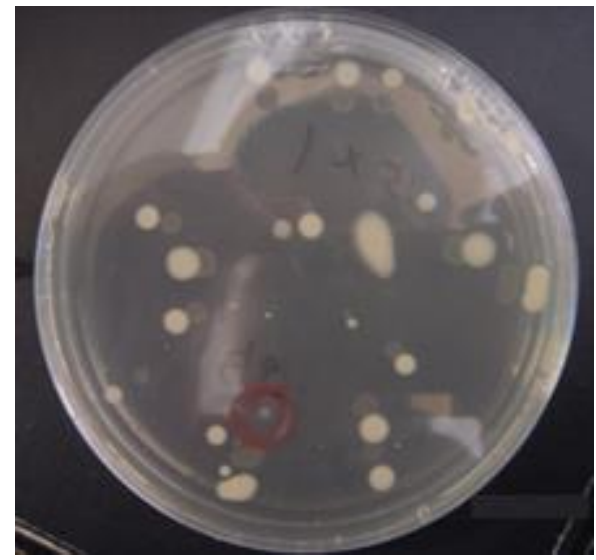

Figure 3. Staphylococcus sp. (No. P-100826-4-6) derived from Corallina officinalis L.

\subsection{Purification of Compounds $\mathbf{1}-\mathbf{7}$}

After filtration, the broth was extracted three times with $10 \mathrm{~L}$ EtOAc. The EtOAc extract was completely dried to produce EtOAc extract (5.2 g). The water layer was subjected to Diaion HP-20 column eluting with water, $60 \% \mathrm{MeOH}, 100 \% \mathrm{MeOH}$, and acetone correspondingly to yield eluted fractions of $60 \% \mathrm{MeOH}(28.3 \mathrm{~g})$ and $100 \% \mathrm{MeOH}(8.0 \mathrm{~g})$, and acetone $(3.9 \mathrm{~g})$. The EtOAc extract was chromatographed on silica gel column using $\mathrm{CHCl}_{3}: \mathrm{MeOH} ;$ 10:0 0:10 to yield 25 fractions.

The 15th fraction (96 mg) was subjected to Sephadex $\mathrm{LH}-20$ using $\mathrm{CHCl}_{3}: \mathrm{MeOH} ; 1: 1$ as eluent to yield four sub-fractions (fractions A-D). Fraction D (10 mg) was purified on ODS column using $50 \%$ $\mathrm{MeOH}: \mathrm{H}_{2} \mathrm{O}$ to give compound $2(7 \mathrm{mg})$.

The 18th fraction (198 mg) was subjected to Sephadex $\mathrm{LH}-20 \mathrm{CHCl}_{3}: \mathrm{MeOH} ; 1: 1$ to give three fractions (fractions A-C). Fraction B (125 mg) was chromatographed on ODS column using 50\% $\mathrm{MeOH}: \mathrm{H}_{2} \mathrm{O}$ followed by final purification on Sephadex $\mathrm{LH}-20$ eluted with $\mathrm{CHCl}_{3}: \mathrm{MeOH} ; 1: 1$ to obtain compound 3 (86 mg). Fraction C (15 mg) was subjected to RP-HPLC Develosil C-30 using 55\% $\mathrm{MeOH}: \mathrm{H}_{2} \mathrm{O}$ to give compound $4(8 \mathrm{mg})$.

The 20th fraction ( $476 \mathrm{mg}$ ) was subjected to Sephadex $\mathrm{LH}-20$ eluted with $\mathrm{CHCl}_{3}: \mathrm{MeOH} ; 1: 1$ to give three sub-fractions (fractions A-C). Fraction A (290 mg) was chromatographed on silica gel column with $\mathrm{CHCl}_{3}: \mathrm{MeOH} ; 10: 0 \sim 0: 10$ as eluent to afford three fractions. Fraction A-1 (50 mg) was finally purified on RP-HPLC Wakosil 5C-18 using 70\% MeOH- $\mathrm{H}_{2} \mathrm{O}$ to afford compound $\mathbf{1}(8 \mathrm{mg})$. Fraction C (35mg) was recrystallized from $\mathrm{MeOH}$ to yield compound $5(31 \mathrm{mg})$. Dissolution of the $100 \% \mathrm{MeOH}$ fraction $\left(8.0 \mathrm{~g}\right.$ ) was done using $\mathrm{CHCl}_{3}: \mathrm{MeOH}: \mathrm{H}_{2} \mathrm{O} ; 5: 5: 1$ to afford soluble fraction (4.7 g). The soluble fraction was subjected to Sephadex $\mathrm{LH}-20$ using $\mathrm{CHCl}_{3}: \mathrm{MeOH}$; 1:1 to obtain seven sub-fractions (fractions A-G). Fraction D (587 mg) was chromatographed on ODS column using MeOH: $\mathrm{H}_{2} \mathrm{O}$ gradient elution to give seven fractions. Fraction D-1 (45 mg) was chromatographed on Sephadex LH-20 using $\mathrm{CHCl}_{3}: \mathrm{MeOH} ; 1: 1$ isochratic elution to obtain two fractions (fractions D-1a and D-3b). Medium 
pressure liquid chromatography (MPLC) used for final purification of fraction D-3b (17 mg) using $\mathrm{CHCl}_{3}: \mathrm{MeOH} ; 98: 2$ as eluent to give compound 6 (5.5 mg). Fraction D-6 (95 mg) was subjected to silica gel column using gradient elution of $\mathrm{CHCl}_{3}: \mathrm{MeOH}$ to give four fractions (fractions D-6a-D-6d). Fraction D-6c $(40 \mathrm{mg})$ was finally isolated on Sephadex $\mathrm{LH}-20$ using $\mathrm{CHCl}_{3}: \mathrm{MeOH} ; 1: 1$ to obtain compound 7 (26.7 mg).

Compound 1: Cyclo (2 $\alpha$, 3-diamino-propoinc acid-L-Asn-3- $\beta$-hydroxy-5-methyl-tetradecanoic acid-L-Leu ${ }^{1}$-L-Asp-L-Val-L-Leu $\left.{ }^{2}-L-L e u^{3}\right)$ : White amorphous powder $[\alpha]_{D}^{30}-29.8^{\circ}(c=0.01$, pyridine); IR $v_{\max }$ (dry film) 3318, 2965, 2862, 1733, $1684 \mathrm{~cm}^{-1} ;{ }^{1} \mathrm{H}$ and ${ }^{13} \mathrm{C}$ NMR data (see Table 1); (HRFABMS) elemental composition $[\mathrm{M}+\mathrm{Na}]^{+}$at $m / z 1016.6396$ (calcd for $\mathrm{C}_{49} \mathrm{H}_{87} \mathrm{~N}_{9} \mathrm{NaO}_{12}, 1016.6372, \Delta+2.5 \mathrm{mmu}$ ), (+) FABMS m/z: $994.7[\mathrm{M}+\mathrm{H}]^{+}$(Figures S1-S3).

\subsection{Configuration of Amino Acids}

Hydrolysis of $1.5 \mathrm{mg}$ of compound 1 was achieved using $1 \mathrm{~mL}$ of $6 \mathrm{~N} \mathrm{HCl}$ for $16 \mathrm{~h}$ at $110{ }^{\circ} \mathrm{C}$. Concentration for the resulting hydrolysate was followed by complete dryness under a vacuum to afford a residue. Dissolution of the solid residue was achieved in $50 \mu \mathrm{L}$ of pure $\mathrm{H}_{2} \mathrm{O}$ and $40 \mu \mathrm{L}$ of $1 \mathrm{M}$ $\mathrm{NaHCO}_{3}$ aq. and $100 \mu \mathrm{L}$ of $1 \%$ of (2S)-2-(5-fluoro-2,4-dinitroanilino)-4-methylpentanamide (FDLA) dissolved in acetone. Heating of the formed mixture was performed for $1 \mathrm{~h}$ at $37^{\circ} \mathrm{C}$, followed by adding $20 \mu \mathrm{L}$ of $1 \mathrm{~N} \mathrm{HCl}$. A yellow solid was formed after complete drying of the previously prepared solution. The resulting solid was dissolved in $40 \% \mathrm{MeCN}_{\mathrm{H}} \mathrm{H} \mathrm{O}(500 \mu \mathrm{L})$ and co-injected with standard D- and L- amino acids using RP-HPLC (UV detector: $340 \mathrm{~nm}$, flow rate: $1 \mathrm{~mL} / \mathrm{min}$, mobile phase: $40 \% \mathrm{MeCN}: \mathrm{H}_{2} \mathrm{O}$ ).

\subsection{Antimicrobial Activity of Compounds 1-7}

Antimicrobial activities of the pure compounds were checked using paper disk methods [28,29] against Staphylococcus aureus subsp. aureus, Escherichia coli, Pseudomonas aeruginosa, Aspergillus niger, Schizophyllum commune, and Penicillium crustosum, with concentration 100 and $50 \mu \mathrm{g} / \mathrm{disk}$. Determination of the MIC for compound 6 was achieved by using tube-dilution method [30].

\section{Conclusions}

Chemical study of the antimicrobial extracts obtained from Staphylococcus sp. derived from Corallina officinalis L., yielded a new cyclic depsipeptide (1) along with the known compounds indol-3-carboxylic acid (2), 1,5-dideoxy-3-C-methyl arabinitol (3), thymine (4), uracil (5), cyclo (L-pro-L-omet) (6), and macrolactin $\mathrm{B}$ (7). The structure of the isolated compounds were elucidated by extensive spectroscopic methods including $\left({ }^{1} \mathrm{H}\right.$ NMR, ${ }^{13} \mathrm{C}$ NMR, COSY, HMBC, HSQC, NOESY, HRFABMS, and IR). The antimicrobial activities of the isolated compounds were evaluated. Compounds $\mathbf{1}-\mathbf{5}$, and $\mathbf{7}$ slightly showed an inhibition zone against Schizophyllum commune, Escherichia coli, and Staphylococcus aureus subsp. aureus, while compound 6 exhibited a potent antifungal activity against Aspergillus niger, Penicillum crustosum, and Schizophyllum commune, with MIC value $50 \mu \mathrm{g} / \mathrm{mL}$. Additionally, compound 6 showed antibacterial activity against Escherichia coli, Staphylococcus aureus subsp. aureus, and Pseudomonas aeruginosa with MIC $100 \mu \mathrm{g} / \mathrm{mL}$.

Supplementary Materials: The following are available online at http://www.mdpi.com/2218-1989/9/11/273/s1, Figure S1: Elemental composition of compound 1, Figure S2: FABMS spectrum of compound 1, Figure S3: FABMS fragments of compound 1, Figure S4: ${ }^{1} \mathrm{H}-\mathrm{NMR}$ spectrum of compound 1 (pyridine- $\mathrm{d}_{5}$ ), Figure S5: ${ }^{13} \mathrm{C}-\mathrm{NMR}$ spectrum of compound 1 (pyridine- $\mathrm{d}_{5}$ ), Figure S6: HSQC spectrum of compound 1 (pyridine- $\mathrm{d}_{5}$ ), Figure S7: HMBC spectrum of compound 1 (pyridine- $\left.\mathrm{d}_{5}\right)$, Figure S8: ${ }^{1} \mathrm{H}-{ }^{1} \mathrm{H}$ COSY spectrum of compound $1\left(\right.$ pyridine- $\left._{5}\right)$, Figure S9: NOESY spectrum of compound 1 (pyridine- $\left.\mathrm{d}_{5}\right)$.

Author Contributions: R.F.A.A. and K.Y. designed the experiments. A.I.M.K. and K.Y. collected the marine specimen. A.I.M.K. and R.F.A.A. performed the experiments. A.I.M.K., A.O.N. and D.M.A. performed the biological activity study. A.I.M.K., A.A.B., S.S.E. and G.T.M. analyzed the data. S.S.E. and A.I.M.K. wrote and edited the manuscript. 
Funding: This research received no external funding.

Acknowledgments: We are indebted to the Scientific Support Section of Joint Research Center, Nagasaki University, especially to Nobuaki Tsuda and Kazufumi Chifuku for performing the NMR and MS spectra measurements. We are also greatly indebted to the Japan Society for the Promotion of Science for supporting this work in part by a Grant-in-Aid for Scientific Research No. 26460124 and 18K06718.

Conflicts of Interest: All authors affirm that there are no conflicts of interest to disclose, whether financial or of any other nature.

\section{References}

1. Newman, D.J.; Cragg, G.M.; Snader, K.M. Natural products as sources of new drugs over the period 1981-2002. J. Nat. Prod. 2003, 66, 1022-1037. [CrossRef] [PubMed]

2. Newman, D.J.; Cragg, G.M. Natural products as sources of new drugs over the 30 years from 1981 to 2010. J. Nat. Prod. 2012, 75, 311-335. [CrossRef] [PubMed]

3. Harvey, A.L. Natural products in drug discovery. Drug Discov. Today 2008, 13, 894-901. [CrossRef] [PubMed]

4. Fenical, W. Chemical studies of marine bacteria: Developing a new resource. Chem. Rev. 1993, 93, 1673-1683. [CrossRef]

5. Blunt, J.W.; Carroll, A.R.; Copp, B.R.; Davis, R.A.; Keyzers, R.A.; Prinsep, M.R. Marine natural products. Nat. Prod. Rep. 2018, 35, 8-53. [CrossRef] [PubMed]

6. Blunt, J.W.; Copp, B.R.; Munro, M.H.; Northcote, P.T.; Prinsep, M.R. Marine natural products. Nat. Prod. Rep. 2010, 27, 165-237. [CrossRef] [PubMed]

7. Faulkner, D.J. Marine natural products. Nat. Prod. Rep. 2002, 19, 1-48. [PubMed]

8. Fenical, W.; Jensen, P.R. Marine microorganisms: A new biomedical resource. In Pharmaceutical and Bioactive Natural Products; Springer: Berlin/Heidelberg, Germany, 1993; pp. 419-457.

9. Lu, X.; Cao, X.; Liu, X.; Jiao, B. Marine microbes-derived anti-bacterial agents. Mini Rev. Med. Chem. 2010, 10, 1077-1090. [CrossRef] [PubMed]

10. Blunt, J.W.; Copp, B.R.; Keyzers, R.A.; Munro, M.H.G.; Prinsep, M.R. Marine natural products. Nat. Prod. Rep. 2017, 34, 235-294. [CrossRef] [PubMed]

11. Andryukov, B.G.; Mikhaylov, V.V.; Besednova, N.N.; Zaporozhets, T.S.; Bynina, M.P.; Matosova, E.V. The Bacteriocinogenic Potential of Marine Microorganisms. Russ. J. Mar. Biol. 2018, 44, 433-441. [CrossRef]

12. Chen, E.; Chen, Q.; Chen, S.; Xu, B.; Ju, J.; Wang, H. Mathermycin, a Lantibiotic from the Marine Actinomycete Marinactinospora thermotolerans SCSIO 00652. Appl. Environ. Microbiol. 2017, 83, e00926-17. [CrossRef] [PubMed]

13. Andryukov, B.; Mikhailov, V.; Besednova, N. The Biotechnological Potential of Secondary Metabolites from Marine Bacteria. J. Mar. Sci. Eng. 2019, 7, 176. [CrossRef]

14. Bohringer, N.; Fisch, K.M.; Schillo, D.; Bara, R.; Hertzer, C.; Grein, F.; Eisenbarth, J.H.; Kaligis, F.; Schneider, T.; Wagele, H.; et al. Antimicrobial Potential of Bacteria Associated with Marine Sea Slugs from North Sulawesi, Indonesia. Front. Microbiol. 2017, 8, 1092. [CrossRef] [PubMed]

15. Felnagle, E.A.; Jackson, E.E.; Chan, Y.A.; Podevels, A.M.; Berti, A.D.; McMahon, M.D.; Thomas, M.G. Nonribosomal peptide synthetases involved in the production of medically relevant natural products. Mol. Pharm. 2008, 5, 191-211. [CrossRef] [PubMed]

16. Miller, B.R.; Gulick, A.M. Structural Biology of Nonribosomal Peptide Synthetases. Methods Mol. Biol. 2016, 1401, 3-29. [PubMed]

17. Elhady, S.S.; Al-Abd, A.M.; El-Halawany, A.M.; Alahdal, A.M.; Hassanean, H.A.; Ahmed, S.A. Antiproliferative Scalarane-Based Metabolites from the Red Sea Sponge Hyrtios erectus. Mar. Drugs 2016, 14, 130. [CrossRef] [PubMed]

18. Alahdal, A.; Asfour, H.; Ahmed, S.; Noor, A.; Al-Abd, A.; Elfaky, M.; Elhady, S. Anti-Helicobacter, Antitubercular and Cytotoxic Activities of Scalaranes from the Red Sea Sponge Hyrtios erectus. Molecules 2018, 23, 978. [CrossRef] [PubMed]

19. Asfour, H.Z.; Awan, Z.A.; Bagalagel, A.A.; Elfaky, M.A.; Abdelhameed, R.F.A.; Elhady, S.S. Large-Scale Production of Bioactive Terrein by Aspergillus terreus Strain S020 Isolated from the Saudi Coast of the Red Sea. Biomolecules 2019, 9, 480. [CrossRef] [PubMed] 
20. Khedr, A.I.M.; Mohamed, G.A.; Orabi, M.A.A.; Ibrahim, S.R.M.; Yamada, K. Staphylopeptide A, a new cyclic tetrapeptide from culture broth of Staphylococcus sp. Phytochem. Lett. 2015, 13, 11-14. [CrossRef]

21. Li, G.-Q.; Deng, Z.-W.; Li, J.; Fu, H.-Z.; Lin, W.-H. Chemical constituents from starfish Asterias rollestoni. J. Chin. Pharm. Sci. 2004, 13, 81-86.

22. Tang, J.; Gao, H.; Hong, K.; Jiang, M.; Zhou, G.; Wang, N.; Yao, X. Secondary metabolites from a mangrove bacterium Bacillus sp. Chin. J. Med. Chem. 2008, 18, 206-209.

23. Kitajima, J.; Ishikawa, T.; TANAKA, T.; IDA, Y. Water-soluble constitutents of fennel. IX. glucides and nucleosides. Chem. Pharm. Bull. 1999, 47, 988-992. [CrossRef]

24. Yang, X.-Q.; Yang, Y.-B.; Zhou, H.; He, G.-W.; Zhao, L.-X.; Xu, L.-H.; Ding, Z.-T. New megastigmane glycoside and alkaloids from Streptomyces sp. YIM 63342. Nat. Prod. Res. 2013, 27, 1191-1196. [CrossRef] [PubMed]

25. Zheng, C.-J.; Lee, S.; Lee, C.-H.; Kim, W.-G. Macrolactins O-R, glycosylated 24-membered lactones from Bacillus sp. AH159-1. J. Nat. Prod. 2007, 70, 1632-1635. [CrossRef] [PubMed]

26. Ibrahim, S.R.; Min, C.C.; Teuscher, F.; Ebel, R.; Kakoschke, C.; Lin, W.; Wray, V.; Edrada-Ebel, R.; Proksch, P. Callyaerins $\mathrm{A}-\mathrm{F}$ and $\mathrm{H}$, new cytotoxic cyclic peptides from the Indonesian marine sponge Callyspongia aerizusa. Biorg. Med. Chem. 2010, 18, 4947-4956. [CrossRef] [PubMed]

27. Ibrahim, S.R.M.; Edrada-Ebel, R.; Mohamed, G.A.; Youssef, D.T.A.; Wray, V.; Proksch, P. Callyaerin G, a new cytotoxic cyclic peptide from the marine sponge Callyspongia aerizusa. Arkivoc 2008, 164-171. [CrossRef]

28. Kiehlbauch, J.A.; Hannett, G.E.; Salfinger, M.; Archinal, W.; Monserrat, C.; Carlyn, C. Use of the National Committee for Clinical Laboratory Standards guidelines for disk diffusion susceptibility testing in New York state laboratories. J. Clin. Microbiol. 2000, 38, 3341-3348. [PubMed]

29. Bonev, B.; Hooper, J.; Parisot, J. Principles of assessing bacterial susceptibility to antibiotics using the agar diffusion method. J. Antimicrob. Chemother. 2008, 61, 1295-1301. [CrossRef] [PubMed]

30. Jorgensen, J.H.; Turnidge, J.D. Susceptibility test methods: Dilution and disk diffusion methods. In Manual of Clinical Microbiology, 11th ed.; American Society of Microbiology: Washington, DC, USA, 2015; pp. 1253-1273.

(C) 2019 by the authors. Licensee MDPI, Basel, Switzerland. This article is an open access article distributed under the terms and conditions of the Creative Commons Attribution (CC BY) license (http://creativecommons.org/licenses/by/4.0/). 